\title{
Can the Gandharvas Speak?: A Study of Gandharva Songs
}

\author{
Bharat Raj Dhakal \\ School of Development and Social Engineering, Pokhara University, Nepal
}

\begin{abstract}
Article History: Submitted 15 February 2021; Reviewed 15 April 2021; Accepted 20 April 2021 Corresponding Author: Bharat Raj Dhakal, Email: bdhakal79@gmail.com DOI: https://doi.org/10.3126/paj.v4i0.37017

Copyright 2021 ( ) Author/s and Centre for Research and Innovation. This work is licensed under a Creative Commons Attribution 4.0 International (CC BY 4.0) License.
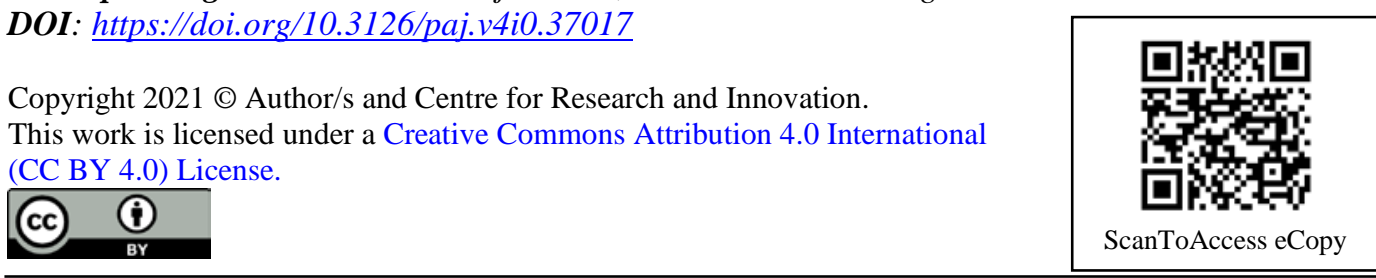

\begin{abstract}
In the social context of Nepal, Gandharvas are regarded as Dalits, the people who are suppressed and silenced by the society. Such subaltern groups are thought to have no voice. They are considered 'muted' or 'inarticulate' without any agency, consciousness and power of resistance. However, breaking such boundaries, the present research aims at exploring the voices of Gandharvas expressed through their folk songs, which express their real subaltern condition and a sense of dissatisfaction towards the mechanism of society constructed and controlled by the elites. For this, some of the representative folk songs are taken and viewed from the perspective of subaltern voice, consciousness, resistance and agency developed by Antonio Gramsci, Ranjit Guha, Dipesh Chakrabarty, Partha Chatterjee and Gautam Bhadra. With the thorough analysis of their songs, it is inferred that although they are deprived of any rank and recognition in the mainstream Nepali society, they have clearly expressed their voices as well as manifested consciousness, reflecting their real life experiences marked by domination, marginalization and suppression. The manifestation of such consciousness and expression of inner voice is also used as an instrument to subvert the hegemony constructed by the complacent upper class of the society.
\end{abstract}

KEYWORDS: Gandharva, subaltern, consciousness, voice, subversion

\section{INTRODUCTION}

This paper aims to analyze the voices of Gandharvas expressed through their folk songs, and how these songs subvert the hegemony constructed by the elites or the mainstream upper class of the society. The paper also explores how they manifest their "consciousness," which has been suppressed by the mainstream higher class of the society.

Gandharvas, in the context of Nepal, are regarded as subaltern groups, the groups deprived of any recognition and rank in the socioeconomic hierarchy of a society. Subaltern groups, for Gramsci (1996), are “Non-hegemonic groups or classes” (p. 20) 
whom he sometimes mentions as ““"subordinate," "subaltern” or sometimes instrumental" (p. 20). These subaltern social groups include "Dalits, religious minorities/Muslims, and class politics/Left - are also structured by centering power that is accrued by the same social structure that also marginalizes them" (Thirumal \& Dickens, 2020, p. 4.). Focusing on the wider attributes, Guha (1982), regards subaltern as "a name for the general attribute of subordination in south Asian Society whether this is expressed in terms of class, caste, age, gender and office or in any other way" (p. VII). Viewing Gandharvas from these two critical lenses, they can also be classified as subaltern groups because they are regarded as Dalits, the "caste groups, located at the bottom of the caste hierarchy, that are more or less horizontally and culturally homogenous (in terms of the discrimination endured), but vertically hierarchized" (Pariyar \& Lovett, 2016, p. 136). This definition of Dalit is compatible with the social and political condition of Gandharvas.

It is widely discussed that such groups, without any agency and prestigious position in the socioeconomic hierarchy, do not have their own voices to manifest their consciousness. Focusing on the lack of voice of such groups, Spivak (1988) argues that the 'true' subalterns "whose identity is its difference, there is no unrepresentable subaltern subject that can know and speak itself" (p. 32). She further asks, "How can we touch the consciousness of the people, even as we investigate their politics? With what voice-consciousness can the subaltern speak?” (p. 32). In other words, she is of the view that subaltern cannot speak. They lack consciousness and agency. They cannot represent themselves, rather they are to be represented. According to her, subalterns have no individuality, choice and action through which they speak and control their representation. Adding to this, Upreti (2008) explains Spivak's idea about subaltern's speaking as "Subalterns are deprived of the access of the public means of expressions like newspaper, radio, television through which they can express their voice. Since they cannot represent themselves, they are thrown outside the elite historiography. Therefore, it is the responsibility of intellectual to speak for them and explore their life philosophy" (My translation, p. 16). Pointing towards the lack of means of expression, scholars like Upreti realize the responsibility of intellectuals to give the voice to the voiceless subalterns. However, such scholars have not noticed that only speaking in some campaigns or delivering speech in public is not the only means of expression. The subalterns can use various means of expressions for giving voice to their own experience.

Realizing that there are various means of giving voice to the inner feeling of subalterns, this paper claims that Gandharvas as subalterns have their own voice which they express through their songs. Their songs also display that they have a clear theoretical consciousness and the spirit of resistance. In the like manner, their songs also display that they have some sort of agency through which they try to bring change in the local, social, political and economic systems. These songs represent Gandharvas' real life situation filled with marginalization, victimization and negligence. Not only this, these songs also reflect their dissatisfaction with their present state of affairs, which means they no longer feel to suppress their voices.

The songs are taken form the Gandharva Sangit Ra Sanskriti, an anthology by Purna Nepali and The Real Folk Music of Nepal: "The Nepalese Blues" collected by Hans Wiesethaunet. The literal translation or the meanings of the extracts are presented. These songs are taken as instruments to explore how subalterns manifest their consciousness, thereby subverting the hegemony through their songs as their real voice. For this, Gramsci's notion of hegemony and subaltern consciousness, Guha's concept of consciousness and the spirit of resistance, Chakrabarty's views on subaltern rebellion 
and Chatterjee's ideas on caste and the consciousness of subaltern along with the views of other thinkers are taken as the principal critical lenses in this paper.

\section{SUBALTERNS AND THE CONCEPT OF RESISTANCE}

Subaltern Studies has now emerged as a subject of global intellectual discussion expanding its scope in different issues of subaltern. In the contemporary time, it started to include vast areas for the debate like the issue of subaltern consciousness, their voice, agency, notion of resistance, etc. Some well-known theorists to talk about various issues of subaltern are Gramsci, Guha, Spivak, Dipesh Chakrabarty, Partha Chatterjee, Gautam Bhadra, etc.

Gramsci (1996) provides us a vivid idea about the subaltern consciousness. He sees that although subalterns have "no clear theoretical consciousness of (his) practical activity" (p. 333), they have some understanding of the world. They have 'one contradictory consciousness' which is composed of two aspects: one autonomous or original and other borrowed. Talking about subaltern, he remarks: "He has two theoretical consciousness (or one contradictory consciousness): One which is implicit in his activity and which in reality unites him with all his fellow-workers in the practical transformation of the real world; and one, superficially explicit or verbal, which he had inherited form the past and uncritically absorbed" (p. 333). This implicit consciousness comes out of his understanding of the world. It enables him to understand the hegemonic structures of the world and to resist against it by uniting other members of the subaltern group. This solidarity, which subalterns construct through their implicit consciousness further encourages them to change the world. But, the explicit consciousness which he inherits from the past is the result of the ideological control of ruling class and the assent of the subaltern class. Here, law, education, media and religion play a pivotal role to achieve the ideological control over subaltern class by the ruling class. These socializing agencies "promote and legitimize the ideas of ruling class to the point where such values are accepted uncritically and unconsciously as normal” (Slattery, 2003, p. 122). Therefore, this explicit consciousness reveals the submissive mentality of subalterns.

According to Gramsci (2003), this conception or the consciousness about the world gets manifested in fragments, "occasionally in flashes" (p. 327) in their action when they have become a 'State' or united. But on the other times, they adopt borrowed conception and "affirm(s) this conception verbally and believe(s) itself to be following it” (p. 327). It means that, in normal times, they do not have any consciousness through which they can be enlightened and emancipated. In this matter, Acharya (2007) states "though the contradictory consciousness holds a social group together, it weakens their action, decision, and choice and finally leads to moral and political passivity" (p. 82). Although manifested in 'flashes', the consciousness, if gets a proper means of expression, can have a lasting effect.

To explore about the subaltern group's need of resistance and victory over elite domination and hegemony are the underlying motives of Gramsci. According to him, the subaltern classes are deprived of means by which they can represent themselves independently of elites and raise voice against the elite groups. They also have less access to social and cultural institution. So, they are in the prison of elite social, political and cultural structures. The only way to get rid of this domination is the permanent victory. But for that they have to be united or become a 'State'. He views, "The subaltern classes, by definition are not united and cannot unite until they are able to become a 'State'” (p. 52). Here 'State' refers to the unity and power of subaltern groups against the domination of elites.

Prithvi Academic Journal, Volume 4, May 2021 [pp. 84-95] $86 \mid \mathrm{P}$ a g e 
It is almost impossible to find an egalitarian society in the contemporary world. The different groups are always in conflict with each other due to inequalities in various forms. In such a situation, one group always tries to dominate and rule over other group. However, there are also different means to dominate and rule over others. This can be either by coercion, armed force, economic control, law, or by hegemony. To rule only by economic control or even by political force alone is almost impossible. The ideological control and the assent of the people also play the vital role of domination. Therefore, Gramsci (1996) expresses:

. . . the supremacy of a social group manifests itself in two ways, as "domination" and as 'intellectual and moral leadership". A social group dominates antagonistic groups, which it tends to "liquidate", or to subjugate perhaps even by armed force: it leads kindered and allied groups. A social group can, and indeed must already exercise "leadership" before winning governmental power (this indeed is one of the principal conditions for the winning of such power); it subsequently becomes dominant when it exercises power, but even if it holds it firmly in its grasp, it must continue to 'lead' as well. (pp. 57-58)

A true subaltern revolution will, therefore, first requires an intellectual struggle against elite ideology, its flaws, its exploitation and its naked oppressions to provide a basis for a new social order in which the subaltern class seizes the philosophical and moral leadership before gaining political and economic control of the state and society.

However, Guha (1982), more than Gramsci, sees subaltern (which he equates as "people") having clear theoretical consciousness and the spirit of resistance. According to him, two types of elitism have been dominating the historiography of Indian nationalism from a long time: colonialist elitism and bourgeois nationalist elitism. This kind elitist historiography fails to acknowledge subaltern's contribution for India's struggle against British rule. Therefore, he tries to asses "the contribution made by people on their own, that is, independently of the elite to the making and development of this nationalism" (p. 3). According to him, thousands and millions of "people" participated in the nationalist activities that overthrew "the wheels of state apparatus and of elite institutions geared to it" (p. 3). In this regard, he thinks that subaltern's one of "invariant features was a notion of resistance to elite domination" (p. 5). The movements like 'anti-Rowlatt' upsurge of 1919 and the 'Quit India' movement of 1942 are some of the nationalist movements initiated by the subalterns where there was no participation of elites. All these activities of subalterns are clearly indicating that they possess the complete theoretical consciousness, agency and the notion of resistance against elitism.

Chatterjee (1989) also could not remain silent from the debate of subaltern consciousness. He provides his opinion about it in relation to caste and caste ideology, that is, 'dharma'. In his essay, "Caste and Subaltern Consciousness", he builds his view upon Gramsci's ground breaking book Selections from the Prison Notebooks. Gramsci's views on subaltern consciousness, commonsense, unification of subordinate classes, need of resistance against elite domination, and the dominance of 'religion as a constitutive force in subaltern consciousness' provide Chattarjee a special methodological tool to talk about the issue of subaltern consciousness and the notion of resistance.

Chatterjee (1989) provides some examples of empirical work containing detailed observations of how the religious beliefs and practices of subordinate caste groups are quite often based on principles that are contradictory to those of the Brahmanical religion" (p. 109). He not only gives the examples of religious beliefs and practices of lower caste groups which are quite opposite to those of upper castes, but also presents some of the practices that lower caste people often imitate from upper castes not as 
mimicry but as rebellion and counter hegemony. As the evidence of this, he takes recourse to the myth of Balaram Hadi, 'the founder of the Balarami or Balahadi sect'. From the observations of such practices, he tries to see the level of the consciousness of subaltern classes. Balaram Hadi performs the activities like those of Brahmanical traditions like preaching people, keeping disciples, offering tarpan, etc. not as mimicry but as an example of counter hegemony. He has his own interpretations of activities unlike those of Brahmans. From his activities, it can be inferred that Balaram Hadi, a subaltern from both caste and economic status, possesses some sort of voice, consciousness, agency and rebellious nature within him.

While searching the political consciousness in subaltern activities, Chakrabarty (2006) observes such consciousness on peasants who have participated in masses for the nationalist 'struggles against the British'. He clarifies his statement as "the formal granting of the citizenship to the Indian peasant after the achievement of independence from British simply recognized his already political nature” (p. 19). Such political consciousness is good instrument to bring affirmative change in the status quo of subalterns, which further indicates that they have their own voice that can be heard.

The notion of subaltern mentality and consciousness have always been a topic of critical discussion. Many scholars tried to analyze whether subaltern mentality and consciousness incline towards submission or towards defiance. Bhadra (2007), in this context, announces that the mentality of subalternity is the composite of 'defiance' and 'submission' to dominant authority. It means that sometimes they revolt against the authority and disobey its command and sometimes they accept the authority. But focusing on the rebellion of subaltern classes, he further writes: "from recent researches it can be shown that, time and again, the subordinate classes have risen in rebellion because of their faith in some moral order, out of an urge to restore justice” (p. 94). It also indicates that the subalterns can never remain repressed forever.

The notion of agency is another vehemently debated issue of subaltern studies. Critics have their own ideas whether the subalterns have any sort of agency through which they can speak, act, assert individuality, gain freedom, change their social, political and economic level and in short represent themselves independently without the help of elites. Spivak (1988), in this regard, puts her distinct ideas about the agency of subalterns. She thinks that subalterns do not have any agency through which they can speak and act without the help of other. They, she views, do not have any choice, freedom and individuality, thereby, submission to authority. They cannot represent themselves, rather they are to be represented. Their agency remains just in a metaphoric and ironic level. Therefore, they cannot be the agent of change.

But the critics like Guha and Chattarjee view that the subalterns have their own agency which is very essential to bring change in society and nation. Guha thinks that subaltern's spontaneous participation in Indian revolution against the colonial oppression brought change in system. This provides him the basis to believe that they possess consciousness. In the like manner, Chatterjee also gives the example of the member of subaltern class, Balaram Hadi, who brought change in the existing social and religious system of his society. This situation ensures him to announce that the subalterns have agency within them.

\section{GANDHARVA SONGS AND REASSERTING RESISTANCE}

Gandharva songs, in essence, are the composite of the issues of resistance and subversion of hegemony. Though the reproduction of hegemony is one aspect, the resistance against elite domination and ideology is another more essential and more dominant part of their songs. They can never keep themselves under the shadow of 
hegemony, which has 'silenced' their voice. Rather they express their own voices and experiences that were previously marginalized by elite domination and doctrines. The complete hegemonization is never possible because there always remains a tendency to revolt against it. In this regard, Slattery (2003), clarifying Gramscian idea about the temporariness of hegemony expresses, "hegemony can never be complete that struggles for ideological control will always exist among ruling class as well as among the proletariat. The total indoctrination is never possible, even in a totalitarian state" (p. 122). So, they are always in opposition to elite domination and marginalization.

Subaltern Gandharvas are not 'muted' and they do not need to be represented by the ideological standards of dominant group. They compose songs in which the subject matter is mostly about their agony and the painful family life. Besides, they also revolt against the unjust and biased social systems. They express their extreme hatred and anger against the mechanisms of society constructed by the upper class elites and rulers. Talking about their own situation is a kind of revolt which shows the injustices and jaundiced vision of society upon them. In order to represent themselves, they do not need to have any access to the public means of communication like radio, television, newspaper, etc. By nature, they are the people who visit the homes of people and sing their own story. They are "like the singers of Serbia and African countries who sing the saga of nation, narratives of epic grandeur and stories of the communities" (Subedi, 2002, p. 127). Being the troubadours of Nepali society, their performativity generates a kind power to represent them through their own standards. Moreover, we also find consciousness in their songs, though in nascent form. Sometimes, they raise highly serious political and social issues which expose their level of consciousness. When they sing to the people to awake, unite and revolt against the discriminations of society, their implicit consciousness becomes clearly visible. This consciousness, however, appears in fragments and flashes.

Their agency can be analyzed from two perspectives. First, they are used by the upper class to express and justify their social position to the public thinking that their songs can produce some kind of effect upon people. Second, within that hegemonic situation, their power of performativity allows them to resist and bring a change at the local level. Both these cases give us the clue that they, to some extent, possess agency. Their songs about public awareness and social participation explore that they have agency which brings change in society on the local level to some extent. However, since they have not achieved 'permanent victory' over hegemony, their agency lies under the shadow. For example, Mani Ram Gaine’s contribution for unification of Nepal during the regime of Prithivi Narayan Shah was highly praiseworthy. The king employed him as a singer who brings change in the mind of warriors and makes them courageous. So, Gandharva songs bring psychological as well as physical change in people and society.

Mainly, their songs are their voices through which they protest against the elite domination. These voices are the texts and documents to prove that that they have their own voice and clear social and political consciousness. Through their songs, we can understand their 'aspirations about the world' and their experience in history. But many historians interested to study about peasants or subaltern classes think that these social groups do not leave behind their own documents. So, Chakrabarty (2006) remarks that those historians "have often turned for help to resources of other disciplines: anthropology, demography, sociology, archaeology human geography etc." (p. 15). But, here, in the case of Gandharvas, they have their songs through which their aspirations and experiences of the world can be noticed. These peasants, though illiterate, are not muted and inarticulate. Their songs are their voices and means of representation. In this regard, Weber (1976) remarks "the illiterate are not in fact inarticulate; they can and do 
express themselves in several ways. Sociologists, ethnologists, geographers, and recently demographic historians have shown us a new and different means of interpreting evidence" (p. xi). Therefore, this also clarifies that out of many ways of giving voice to the real subaltern condition, the song is also one of the ways, which Gandharvas take as instrument to express their real life experience of domination and oppression.

\section{Sukumbasiko Pir Byatha Doshro [Miseries of Squatters-Second]}

To know how Gandharvas are subverting the hegemonic structures constructed by the dominant groups, this song must be studied in contrast to Karkhas; especially the "Shah Banshko Karkha". Through this song, they break the hegemony which they had accepted previously as normal. In Karkhas, they praise the rulers and elites thinking that they are really great and gifted people. In those songs, they also express that they have got everything from the rulers, which is needed to live an easier life. But, in other songs like the present song, they state that they are deprived of even basic needs and exploited by upper class. This song is especially the 'voice' of a squatter who is dissatisfied with the settlement plan of the king.

The so-called idea that the subalterns cannot speak and do not have their own consciousness has been broken in this song also. Boehmer (2006) explaining Spivak's idea of subaltern's speech and consciousness states, "Subaltern consciousness is a product of elite discourse, not a concrete entity in the world; it is a construction of socially authorized language, not a self or subject that can will itself to speak" (p. 354). But quite opposite to this statement, the subaltern Gandharvas show their consciousness not 'as a product of elite discourse' but as the outcome of their own experience and understanding of the world. In this song, the Gandharvas give voice their own opinion against king Mahendra's activities of providing land for the landless people in the jungles of Chitwan.

In this song, Gandharvas reveal their dissatisfaction against the settlement program organized by King Mahendra. They satirize King Mahendra's activities. They say that the land provided by Mahendra to the poor people is not a good land for settlement. It is just a jungle where there is always the fear of flood and wild animals. It is also not good for farming. In the following lines, this idea is clearly manifested.

Dhan kutera chamalu dalima

Gamle jhare Chitwanko jhadima.

$$
\text { [...] }
$$

Koima laune sagpata koima laune aalu

Sukumbasi basne thauma aauchan bagh-bhalu. (Nepali, 2060, p, 534)

[Keeping rice in basket after crushing in machine

Villagers migrated to the bushes of Chitwan

$$
\text { [ ...] }
$$

We grow vegetable in some places whereas potatoes in other

Tigers and bears come in the residents of squatters.] (My Translation.)

The literal meaning of this extract is that elites or the land-lords can grow varieties of crops for their livelihood. But the poor squatters are deprived of such things. Rather, they are troubled by wild animals. This extract exposes the problems of settlement in the new place. King Mahendra provides the land for poor in the jungle of Chitwan where there is the fear of wild animals. So, these people show dissatisfaction against this task of King Mahendra. It is, they think, the biased distribution of land. Are not there other places where they can settle easily? They question indirectly. These lines reveal that they are directly talking to King Mahendra, which means that subalterns can speak. 
Furthermore, there is another example of speaking own voice in the song. The following extract will justify their voice:

Hera Sarkar basana bhayena

Layaun kheti kehi pani rahena. (Nepali, 2060, p, 535)

[Our Lord King, have your eye upon us, impossible to survive

We plant crops but nothing remains, destroyed by wildlife.] (My Translation.)

In this extract, they directly address King Mahendra. They express their sorrow in these lines. They say that they work hard to grow some grains but in vain. Sometimes it is destroyed by wild animals and sometimes by bad weather. Therefore, they cannot live on such places which were provided by King Mahendra.

Besides, there are some ironical stances in the song also. On the one hand, they glorify King Mahendra but on the other hand they express disagreement on King Mahendra's activities.

Contrarily to the present song, in 'Shah Banshako Karkha', Gandharvas praise King Mahendra as a virtuous and tender king who has provided everything for Gandharvas. They say that he has provided house, land, shelter, food, clothes, education, electricity, etc. to them. They praise him as if he is the God and by his blessing there are not any problems for them. But in this song, they express that they are not getting anything from him. Their song exposes that there is a biased distribution of land. Therefore, they have become the victims of King Mahendra's unjust system. In this way, they subvert the hegemony, which they have accepted in their earlier period. In fact, it is their protest, and "at the beginning of every peasant uprising", Chakrabarty (2006) announces, "there was inevitably a struggle on the part of rebels to destroy all symbols of the social prestige and power of the ruling classes" (p. 10). In doing so, "they are undermining hegemony. Further, the attempts made by the subalterns to subvert dominant cultural forms and meanings ... are efforts to dismantle the sources of power" (Parobo, 2020, p. 184). This also clarifies that their songs are not only their voices but an instrument of undermining hegemony and destroying the symbols of elite power.

\section{Gaule Daju Gaule Bhai [Younger and Elder Brothers of My Village]}

This song paints a grim picture of Subaltern Gandharva life full of domination, poverty and discrimination. In this song, the terrible plight of Gandharva is expressed in a very gloomy tone. By expressing the real experiences of being poor, hungry, neglected and dominated by rich landlords and even by the king, they show their disgrace against the repressive state apparatus. From this song, it can also be inferred that too much tortures finally evokes rebellious mentality.

This song reveals the gap between rich and poor. This song shows the pattern of suppression of the subalterns by the elites within the broad division of society. The people who are under the lines of poverty have to face many problems in the society. They do not have any job, land, food, shelter and money. They do very hard work, irrigate lands with sweat and blood and go to foreign land for the hope of living easy life. But the irony is that the rich people, who are holding the power, snatch their property and Gandharvas are always compelled to live the life under poverty. What they earn from their hard labour ultimately goes to the pocket of elites. The elites live the life of prosperity upon the labour of poor. Instead, the rich people make them work without any wages. So, the lower class people are not being able to make any change in their own economic status because of the direct intrusion of elites. It becomes clear in lines given below:

Prithvi Academic Journal, Volume 4, May 2021 [pp. 84-95] $91 \mid \mathrm{P}$ a g e 
Gaule daju gaule bhai ke dukha payau ni

Sukhako lagi gardachu kama jhan dukha payauni

Jhan dukha paiyoni ...

Himdai bhari paradesh lagyau dhakara banera

Sahule linchan hisapai gari gharama basera

Hajur hisapai garera. (Wiesethaunet, 1997, Track 13)

[Elder brother villager, younger brother villager, what suffering we do get

We work for the happiness, but we are getting more and more trouble

Yes sir, we just get more trouble!

The whole winter we went (travelling) outside being Dakar (having to carry a heavy basket/load)

But the sahu (moneylender/ feudal lord) takes it all

Drawing up the account as he sits in his home

Yes sir, drawing up his accounts!] (Translated by Wiesethaunet, 1997)

The literal meaning of these lines is that the poor Gandharva always labours hard so that one day he can live a comfortable life. But, to his dismay, the more he works hard, the more he gets miseries in life. He also has to go to abroad to pay the loan he has taken which he has to pay. These lines expose a very difficult life of Gandharvas, which is resulted from the exploitation of upper class that is habituated to enjoy upon the labour of them. The lower class people always work hard to be prosperous and make life easy but the rich people seize their assets. They leave the country to get some work and earn money, but the rich elites take money from them. This also shows that these subaltern groups can express their real voices "independently of elite narratives" (Chakrabarty, 1986, p. 374). They do not need to others to represent themselves.

In the context of Nepali society, from the historical period, elites have been dominating the lower class people by various means. Kamaiiya Pratha, Haliya Pratha, false paper of debt and high charge of interest are some of the ways adopted by rich people to dominate the poor. The debt taken from grandfather will never be paid back, and his son and grandson have to pay that debt even by being slave or the ploughman. However, they earn a little from other side works, but that is also captured by the elites. Such situation is clearly depicted in following extract:

Dui char muri bhitryayau bali pran cha tesaima

Tesaima nuna, tesaima lugaa, sahu cha tesaima

Hajur sahu cha tesaima. (Wiesethaunet, 1997, Track 13)

[We harvested just a few muri (Nepalese measure) of the crops, and in that is our life

We have to eat and survive, from this we also have to buy salt, we have to buy clothes, and from this we have to pay the sahu

Sir, in that is the sahu too!] (Translated by Wiesethaunet, 1997)

These lines indicate that elites or the landlords seize their property. The poor people earn a little from their hard work which is every thing for them. They have to manage everything for daily life from that little earning. Moreover, they have to pay the debt to their masters from that, too. The rich people snatch the property of poor people even by devaluing it. They take every thing from the poor for fulfilment of debt.

Their songs expose the real gap between rich and poor through which it becomes easy to analyse the nature of country's indifference towards poor people. They reveal that country's economic as well social policies have neglected the concerns of lower class people and emphasized only on the needs and satisfactions of upper class. It becomes obvious from the following lines:

Sukhile khancha masina chamal tin palta phalera

Prithvi Academic Journal, Volume 4, May 2021 [pp. 84-95] 92 | $\mathrm{P}$ a g e 
Garibale khanchan kodako geda jantoma dalera

Hajur, aansu nai jharera

Dhanile lauchhan barsadi kota shitara talkane

Gariblai chhaina korako bhoto man matrai kalpane

Hajur, man matrai kalpane. (Wiesethaunet, 1997, Track 13)

[The rich eat masina chamal (high quality rice), husking three times

The poor eat the grains of millet crushed in millet stone,

Sir, shedding their very tears!

The rich people will have a long coat...glittering with expensive sequins

The poor do not have even the vests of rough cloth, their minds can only dream

Sir, their minds can only dream!] (Translated by Wiesethaunet, 1997)

This extract depicts the real picture of Nepali society where there is vast gap between rich and poor. The rich people enjoy delicious food and expensive clothes whereas poor people have to sustain their livelihood on the cheap food and old torn clothes. They can just dream about them.

\section{DISCUSSION}

Along with speaking against the existing social order and elite discourse, the level of implicit consciousness is manifested in 'flashes' in their songs. Spivak (1988) thinks that subaltern consciousness is nothing but the ideology constructed by the upper class (p. 32). But, in their song, the Gandharvas express their sorrows before those people who are also the victim of the same social order and try to unite them against the tyranny of upper class. They play the role of intellectuals to unite people. Gramsci (1996) views that the subalterns should become a 'state' (p. 202), that is, to be united and only then, they can negate the hegemony and the exploitation of the upper class. What is lacking is only the organized social movement against the tyranny and injustices. However, they have become able to bring change in the minds of people in the local level to some extent.

Gandharvas are compelled to live the life of subaltern because of the prejudiced and repressive mechanisms constructed by the dominant higher class of the society. The mainstream upper class always tries to suppress their "voice." However, they speak through their songs. Their voices get outlet through their songs. They sing for not only the entertainment and public information but also for the expression of the agony they go through because of the partiality of the social systems constructed by the higher class people. Because of continuous negligence towards their sufferings, they are able to grow a kind of rebellious mentality. They are also able to realize the clear distinction between norms to be followed by elites and paupers. Not only this, develop consciousness to challenge and defy the systems of the privileged groups. Such challenge and defiance ultimately enable them to threaten the hegemony or the ideology of the upper class people. Eventually, they become successful to make a true representation of themselves without taking recourse to the aristocrats. This proves that they can speak and subvert the hegemony of the upper class.

Their songs show clear political consciousness, which is their life philosophy obtained from the real life experience. The consciousness obtained from their life philosophy ultimately enables them to bind in solidarity that eventually brings practical transformation of repressive social system. This transformation also helps to establish common system equally applicable to all. However, they have not achieved the final and permanent victory over repressive social mechanisms. Yet, they have not forgotten their class consciousness. Therefore, they are in the process of changing biased norms of society. 
Another abundantly discussed issue on subaltern studies is resistance. In simple words, resistance is just opposing or challenging those notions or practices that possess threat to the life and obstacles on the path of freedom. This is also a form of defiance of both repression and hegemony. Such idea of resistance is the salient feature of Gandharva songs, too. Through their songs, they condemn the rulers or the leaders of society about the unfair treatment they have to face. They resist all those social, ideological, economic and political forces, which appear as a barrier to the materialization of their dreams of prosperity, opportunity and justice. By singing the songs of real situation of life, they not only repel the hitherto system of partiality but also expose the false representation of their life. Therefore, their songs show that they can represent themselves truly, as they retain the agency.

Gandharva songs challenge the hegemonic constructions of the elites by expressing their real situation. It is assumed that the subaltern groups cannot develop their own consciousness and counter hegemonic position, thereby unable to give voice to their own ideas and life philosophy. Contrary to this, subaltern Gandharvas develop their own consciousness and counter hegemonic stance. Because of such developments, they are able to speak. Analyzing the songs from this lense, it can be proved that Gandharvas have been subverting the elite discourse frequently by developing their own consciousness and spirit of resistance as a counter hegemonic discourse. Accepting hegemonic exploitation as a survival strategy, they have been developing their own subculture, which enables them to understand the forms and natures of exploitation and prepares them to the impending revolution.

\section{CONCLUSION}

Gandharvas speak through their songs. Their songs are their voices, which reflect their pain and suffering imposed by the elites. They reveal that they are deprived of house, land, food, well earning occupation and the prestigious position in society. This situation has risen up their rebellious mentality and the realization of distinction between norms to be followed by elites and paupers and creates a consciousness which leads them to establish their own ideology as a counter hegemonic stance. This consciousness also encourages them to violate the norms of elites. So, by challenging and disobeying the authoritative norms and values, they subvert the hegemonic domination and represent themselves without the help of elites. Hence, they speak through their songs against the social and economic domination by developing their own consciousness, spirit of resistance and agency which are inherent features of their songs.

Gandharva songs manifest that they have political consciousness of their own activities. This consciousness is their life philosophy, which they have obtained from the real life experience that is filled with exploitation, marginalization and victimization. It binds them in solidarity for the practical transformation of repressive social system and helps to establish a social system with justice, equal opportunity and self-esteem. So, this consciousness enables them to create their own voice, own understanding of the world and own vision.

The notion of resistance is another inherent feature of Gandharva songs. They lambast elites for the present downtrodden condition and advocate for the establishment of equality, justice and liberty. These songs also warn them the impending revolution. Through these songs, they have become able to represent themselves according to the ideological standards of their own 'without the thought of elite' which indicates subversion of hitherto system of representation based on the standards of master and slave. The effects of these songs also reveal us that they are the real agent of change 
because through these they have become able to bring change in the existing social systems to some extent though not on national level, but on local level.

Thus, Gandharva songs subvert the hegemonic structures constructed by the mainstream upper class by expressing their real subaltern life. By developing their own consciousness as a counter hegemonic position and resistance, they give voice to their own experience, feelings and thoughts of being treated discriminately by the upper class people and biased social system, which generally thought, is not possible.

\section{REFERENCES}

Acharya, P. (2007). Munoo as the muted subaltern in Ananda's Coolie. Literary studies, 23, 79-90.

Bhadra, G. (2007). The mentality of subalternity: Kantanama or Rajdharama. In R. Guha (Ed.), A subaltern studies reader (pp. 63-69). Oxford University Press.

Boehmer, E. (2006). Postcolonialism. In P. Waugh (Ed.), Literary theory and criticism (pp. 340-361). Oxford University Press.

Chakrabarty, D. (1986). Invitation to a Dialogue. In R. Guha (Ed.), Subaltern studies IV (pp. 364-376). Oxford University Press.

Chakrabarty, D. (2006). Habitations of modernity: Essays in the wake of subaltern studies. Permanent Black.

Chatterjee, P. (1989). Caste and subaltern consciousness. In R. Guha (Ed.), Subaltern studies VI (pp. 169-209). Oxford University Press.

Gramsci, A. (1996). Selections from prison notebooks. (Q. Haore \& G. N. Smith, Trans.). Longman.

Guha, R. (1982). Subaltern studies I. Oxford University Press.

Nepali, P. (2060). Gandharva sangit ra sanskriti. UNESCO.

Pariyar, B., \& Lovett, J. C. (2016). Dalit identity in urban Pokhara, Nepal. Geoforum, 75, 134-147. https://doi.org/10.1016/j.geoforum.2016.07.006

Parobo, P. D. (2020). Histories, identities and the subaltern resistance in Goa. Journal of Human Values, 26(2), 177-185. https://doi.org/10.1177\%2F0971685819891381

Slattery, M. (2003). Key ideas in sociology. Nelson Thornes.

Spivak, G. C. (1988). Can the subaltern speak? In B. Ashroft, G. Giffiths \& H. Tiffin (Eds.), The postcolonial studies reader (pp. 28-37). Routledge.

Subedi, A. (2002). Dalits and Performing Arts. In P. M. Devkota (Ed.), Dalits of Nepal: Issues and Challenges (pp. 119-131). Feminist Dalit Organization.

Thirumal, P. \& Dickens. L. (2020). Incommensurable sacral-secular sectarianism? Rohith Movement and the Emergence of the Inappropriable. In A. Gudavarthy (Ed.), Secular sectarianism: Limits of subaltern politics (pp.1-20). SAGE.

Upreti, S. (2008 March 10). Nepali subaltern bareka prashna. Nayapatrika.

Weber, E. (1976). Peasants into Frenchmen: the modernization of rural France, 18701914. Stanford University Press.

Wiesethaunet, H. (1997). The Real Folk Music of Nepal: "The Nepalese Blues." CD and booklet. Travelling Records. 